\title{
$\widehat{A}$ Madridge \\ madridge Journal of Cancer Study \& Research \\ Interconnecting Scientific World
}

Case Report

Open Access

\section{Granulomatous Mycosis Fungoides Presented as Multiple Subcutaneous Masses: a case of 5-year follow-up and Review of the Literature}

\author{
Yin Fang ${ }^{1}$, Xu Xiao-Yun ${ }^{2}$, Chen Jia ${ }^{3}$, Song Ning-Jing ${ }^{1 \star}$ and Cheng Xing-Wang ${ }^{4 \star}$ \\ ${ }^{\prime}$ Department of Dermatology, Tongren Hospital Shanghai Jiao Tong University School of Medicine, Shanghai, P.R. China \\ ${ }^{2}$ Department of Dermatology, Jiangsu Province Geriatric Hospital, Nanjing, P.R. China \\ ${ }^{3}$ Department of Dermatopathology, Shanghai Skin Diseases Hospital, Shanghai, P.R. China \\ ${ }^{4}$ Department of General surgery, The Shibei hospital of Jingan district, Shanghai, P.R. China
}

\section{Article Info}

*Corresponding authors:
Song Ning-Jing
Tongren Hospital
Shanghai Jiao Tong University School of
Medicine
Shanghai
P.R.China
E-mail: songnj-10@163.com

Cheng Xing-Wang

The Shibei hospital

Jingan district

Shanghai

P.R.China

E-mail: chengxingwangbb@163.com

Received: December 25, 2017
Accepted: January 29, 2018
Published: February 05, 2018

Citation: Fang Y, Xiao-Yun X, Jia C, Ning-Jing $S$, Xing-Wang C. Granulomatous Mycosis Fungoides Presented as Multiple Subcutaneous Masses: a case of 5-year follow-up and Review of the Literature. Madridge J Cancer Stud Res. 2018; 2(1): 34-39.

doi: $10.18689 / \mathrm{mjcsr}-1000104$

Copyright: ( $) 2018$ The Author(s). This work is licensed under a Creative Commons Attribution 4.0 International License, which permits unrestricted use, distribution, and reproduction in any medium, provided the original work is properly cited.

Published by Madridge Publishers

\section{Summary}

Diagnosis of granulomatous mycosis fungoides is very challenging due to its clinical and pathological heterogenicity. We report a case of a 72-year-old female presented with 2 years scaly plaques, 5 months subcutaneous tumours on the sternum and left upper and both side lower extremities.

Keywords: Granulomatous Mycosis Fungoides; Histology; Treatment

\section{Introduction}

Granulomatous mycosis fungoides (GMF) is a rare histological variant of cutaneous T-cell lymphoma (CTCL) [1], which was first described by Ackerman and Flaxman in 1970 [1]. GMF usually presented with non-specific skin lesions such as papule, macule, plaque, desquamation asymptomatic nodule, ulcer or tumor. However, the case of ichthyosiform eruption and subcutaneous mass has been reported rarely. We summarize a case of GMF a 72-year-old female initially presented with scaly plaques and subcutaneous tumors, which progressed to a tumoral cutaneous stage with sternum, anterior abdominal and axillary lymph nodes involvement.

\section{Report}

A 72-year-old woman was referred to our clinic center in August 2012 presented with 2 years scaly plaques, 5 months subcutaneous masses on the sternum and left upper and both side lower extremities. The patient noticed scaly plaques with mild itching on the right lower limb in April 2010. She was hospitalized twice due to ichthyosis in April and June 2010. Ultrasound revealed enlarged lymph nodes in the subclavian, armpit, and groin. Infiltrative plaques appeared on the surface of her right thigh with no obvious symptoms initially, and sooner, similar symptoms and lumps successively emerged on the sternum and left upper and both side lower extremities but no burst. Six months later she was re-admitted. Biopsies showed granuloma formation in the dermis and subcutaneous tissue, with less heteromorphic cells and more giant cells. Immunohistochemical staining revealed that the tumor cells expressed CD3, CD45RO, but they were negative in $\mathrm{L26}, \mathrm{CD} 79 \mathrm{a}, \mathrm{BCl}-2$. Some of atypical cells were $\mathrm{CD} 4^{+}$and $\mathrm{CD} 8^{+}$. $\mathrm{T}$-cell receptor (TCR) gene analysis showed negative expression. Combiningmorphology and immunohistochemical staining with cloned gene rearrangement detection results, there was no certain malignant evidence. However, the rash still had no clear improvement 
and the tumor continued to grow, so she came to our clinic to seek further medical treatment. Further questions about the disease revealed a subcutaneous mass history in her left pinkie without symptoms in September 2008and then spread to her left ring finger. Histopathological recorded as chronic granuloma formation in local hospital and her two fingers were amputated in October 2009.

\section{Clinical Findings}

Infiltrative dark erythematous plaques and desquamation presented in most surface skin in cutaneous examination. Subcutaneous tumors were found on the sternum, left upper and both side lower extremities (Fig. $1 \mathrm{a}, \mathrm{b}, \mathrm{c}$ ) measuring from $2-3 \mathrm{~cm}$ to $6-7 \mathrm{~cm}$. Left little and ring finger were amputated (Fig.1d).

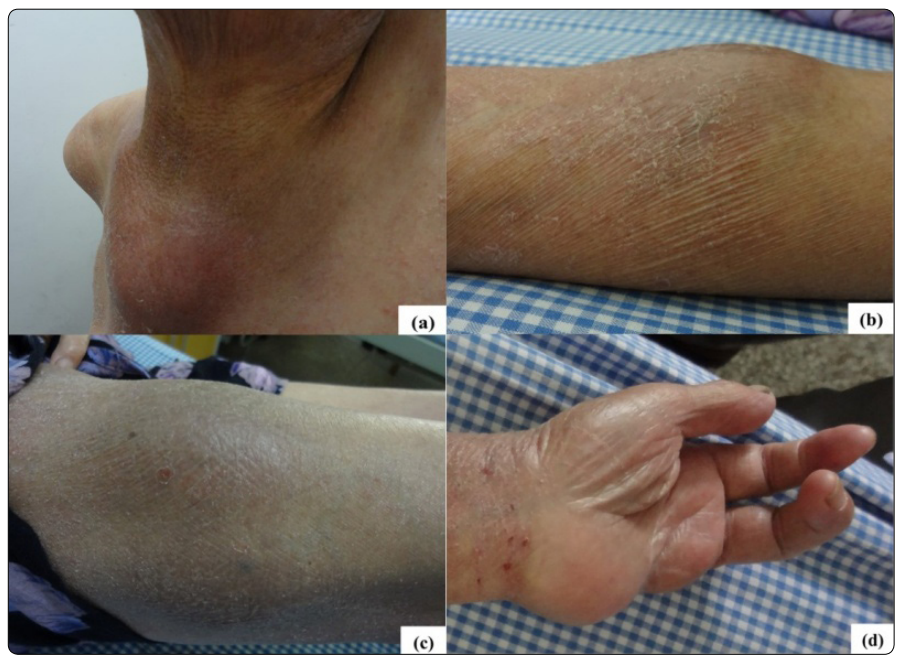

Figure 1. Subcutaneous tumour: (a) sternum; (b) left upper; (c) right lower limb. (d)Left little and ring finger were amputated.

\section{Ultrasound Examination}

Subcutaneous masses appear in both ears, thighs and right anterior chest wall. Lymph node enlargement, especially in the neck and both groin.

\section{Computed Tomography Scan}

The CT scans of the thorax, abdomen and pelvis demonstrated extensive involvements of sternum, anterior abdominal and axillary lymphadenopathy.

\section{Histology and Immunohistology}

Histologically, the right thigh tumor showed that the dermis and hypodermis were massively and multifocal infiltrated by large multinucleated giant cells accompanied by inflammatory cells such as lymphocytes, histocytes and plasma cells (Fig.2). The neoplastic cells displayed a immunophenotype of $\mathrm{CD}^{+}, \mathrm{CD}^{+}, \mathrm{CD}^{+}, \mathrm{CD} 4 \mathrm{RO}^{+}, \mathrm{CD} 68^{+}, \mathrm{S}-$

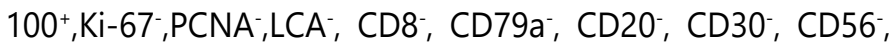
$\mathrm{CD} 1 \mathrm{a}^{-}$(Fig.2) pattern. Immunohistology of axillary lymph node revealed similar results to the right thigh tumor (Fig.2, Fig.3).

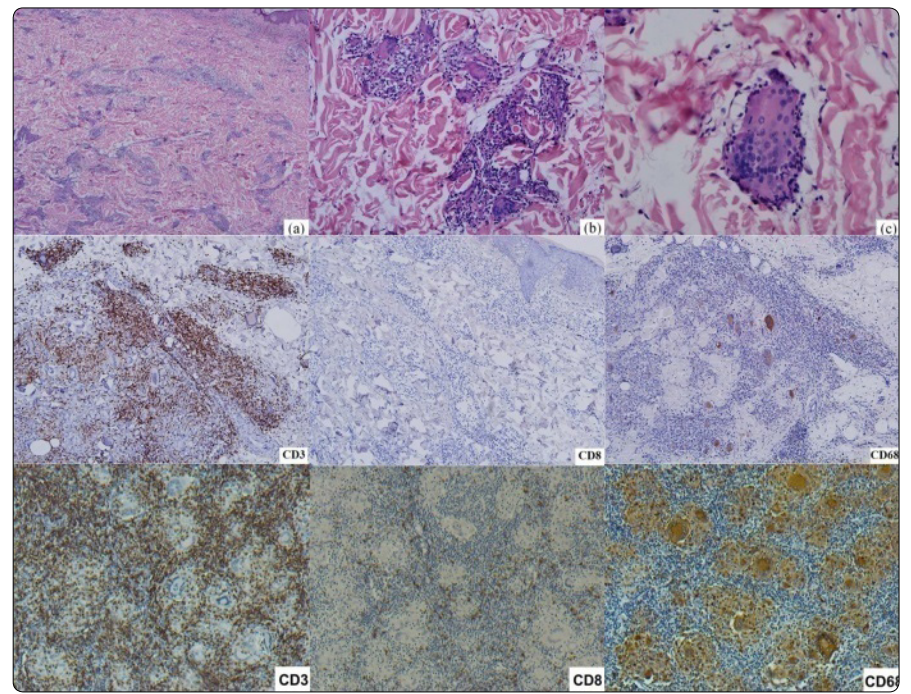

Figure 2. HE and Immunohistochemistry staining :The dermis and hypodermis were massively and multifocal infiltrated by large multinucleated giant cells accompanied by infiltrating inflammatory cells, (a)HE $\times 40$; (b)HEx 100; (c)HE $\times 400$. (right thigh tumour).

Immunohistochemistry staining showing: $\mathrm{CD} 3(+), \times 100$; CD8 $(-), \times 100 ; C D 68(+), \times 100$. (right thigh tumour).CD3 $(+), \times 100$; CD8(+), $\times 100 ;$ CD68(+), $\times 100$.(axillary lymph nodes)

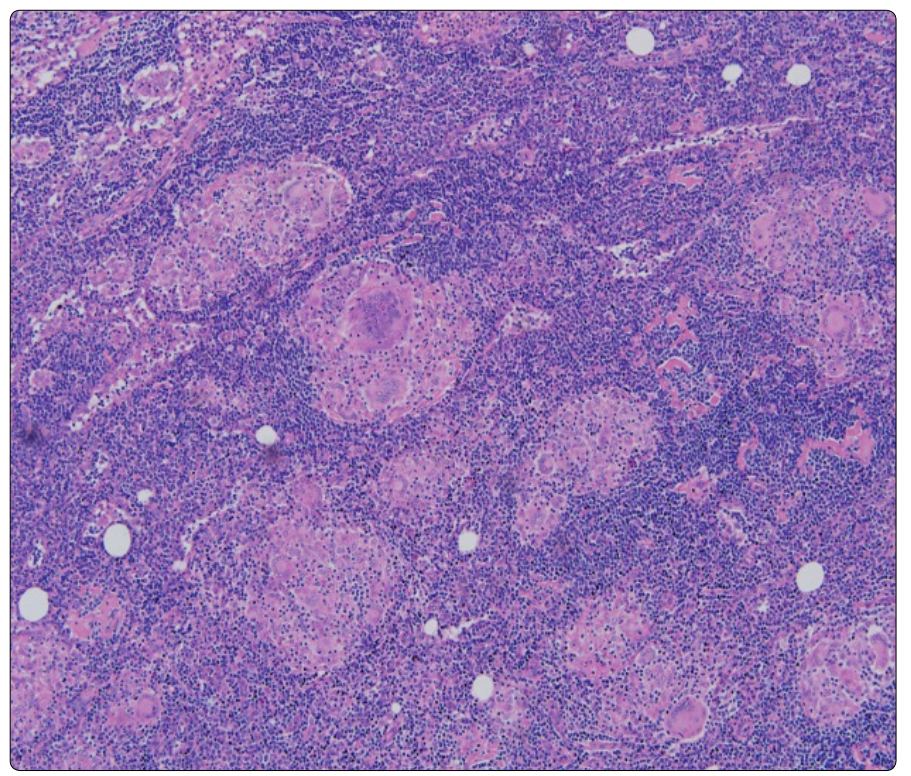

Figure 3. Lymph nodes were massively and multifocal infiltrated by large multinucleated giant cells accompanied by infiltrating inflammatory cells similar to the skin biopsies. HEx100. (axillary lymph nodes)

These results indicated that lymph nodes were also involved.

\section{TCR Gene Analysis}

TCR gene analysis of the right thigh biopsy specimen displayed TCRB ${ }^{+}, \mathrm{TCRD}^{+}$, TCRG-(Fig.4), providing evidence of a $\mathrm{T}$-cell monoclonal proliferation. 


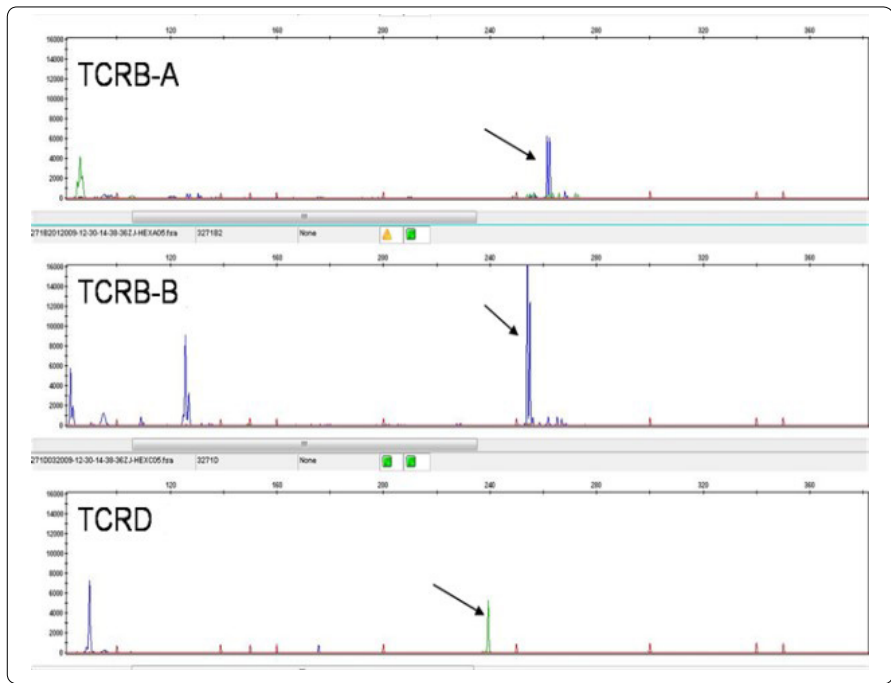

Figure 4. The result of TCR gene analysis: Monoclonal TCR- $\beta$ (TCRB Tube -ADtube-B) and TCR- $\delta$ (TCRD Tube) gene rearrangements were detected; Monoclonal TCR- $\gamma$ gene rearrangements were not detected (TCRG tube -ADtube-B).

\section{Diagnosis}

With the combination of clinical presentation, histopathology, immune histology and TCR gene analysis, the diagnosis of granulomatous mycosis Fungoides (GMF) tumorstage with lymph node involvement was made.

\section{Treatment and Prognosis}

The patient was treated with prednisone $20 \mathrm{mg}$ and isotretinoin $20 \mathrm{mg}$ per day and moisturizer for external use. The masses were gradually disappeared one month after the treatments. The medication doses were tapered off due to the disease progression. Follow-up has been continuing.

\section{Discussing}

Granulomatous mycosis fungoides was first described by Ackerman and Flaxman in 1970, who reported a patient with tumor-stage MF with giant cells dermal infiltration [1]. It is a rare histopathological type of mycosis Fungoides (MF) which exhibited characteristic expression of granulomatous reaction with the atypical lymphocytic infiltration [1]. The clinical manifestations of GMF were lack of specificity, therefore GMF cannot be simply diagnosed from the skin rash. It also needs additional tests, such as histopathology, immune histology and TCR gene analysis.

Since the first case of GMF in 1970, at least 41 cases have been reported in the literature. We summarized the clinicopathologic characteristics, prognosis, and therapeutic responses of GMF (Table 1).

Table 1. Literature review, Case data on clinical features, histological observations, therapy and survival of disease

\begin{tabular}{|c|c|c|c|c|c|c|c|}
\hline NO./Ref. & $\begin{array}{l}\text { Age } \\
\text { /sex }\end{array}$ & Location & Lesion Type & Phenotype & TCR & Therapy & $\begin{array}{l}\text { Survival } \\
\text { (month) }\end{array}$ \\
\hline NO.1/1 & 46/M & thighs abdomen & plaques, nodule, ulcerated & / & / & MTX & $>384$ \\
\hline NO.2/21 & $59 / \mathrm{F}$ & / & $\begin{array}{l}\text { plaques, } \\
\text { erythema }\end{array}$ & / & 1 & $\begin{array}{l}\text { nitrogen mustard } \\
\text { electron beam }\end{array}$ & $>96$ \\
\hline NO.3/22 & $47 / \mathrm{M}$ & & plaques, ulceration, patchesnodule & / & / & carmustine & $>63$ \\
\hline NO.4/23 & $52 / \mathrm{M}$ & & $\begin{array}{l}\text { plaques, ulcerating } \\
\text { tumours }\end{array}$ & & & radiotherapy & 25 \\
\hline NO.5/23 & $59 / \mathrm{M}$ & & $\begin{array}{l}\text { scaly } \\
\text { erythema, }\end{array}$ & & & electron beam & 480 \\
\hline NO.6/23 & $67 / F$ & & $\begin{array}{l}\text { scaly, } \\
\text { plaques, erythroderma }\end{array}$ & & & $\begin{array}{l}\text { electron beam } \\
\text { chlorambucil, } \\
\text { prednisolone }\end{array}$ & 45 \\
\hline NO.7/23 & $81 / F$ & & & & & $\begin{array}{l}\text { electron beam } \\
\text { azarabine }\end{array}$ & 264 \\
\hline NO.8/24 & $38 / F$ & $\begin{array}{l}\text { left forearm } \\
\text { Abdomen } \\
\text { left flank } \\
\text { thigh } \\
\text { knee }\end{array}$ & $\begin{array}{l}\text { nodules, plaques, } \\
\text { erythema }\end{array}$ & $\begin{array}{l}\text { CD2+, CD3+, } \\
\text { CD4+, CD5+, CD7+,CD45+, } \\
\text { HLA-DR+, } \\
\text { CD30- }\end{array}$ & TCR- & $\begin{array}{l}\text { extracorporeal } \\
\text { photopheresis }\end{array}$ & $>142$ \\
\hline NO.9/24 & $33 / \mathrm{M}$ & $\begin{array}{l}\text { legs,calves, } \\
\text { forearms, } \\
\text { back }\end{array}$ & plaques, nodules & $\begin{array}{l}\text { CD2+, CD4+, } \\
\text { CD5+, CD7+, } \\
\text { HLA-DR+, CD30- }\end{array}$ & TCR+ & nitrogen mustard & $>44$ \\
\hline NO.10/25 & $31 / F$ & l & $\begin{array}{l}\text { plaques,ulceration, } \\
\text { atrophic }\end{array}$ & $\begin{array}{l}\text { CD2+, CD3+, } \\
\text { CD4+,CD5+, CD7- }\end{array}$ & / & interferon- $\alpha$ & 62 \\
\hline NO.11/14 & $39 / F$ & $\begin{array}{l}\text { thigh } \\
\text { left flank }\end{array}$ & $\begin{array}{l}\text { plaques } \\
\text { nodules } \\
\text { erythroderma }\end{array}$ & $\begin{array}{l}\text { UCHL1+, CD2+, } \\
\text { CD3+, CD4+, } \\
\text { CD5+, CD30+, } \\
\text { CD7-, CD19-, } \\
\text { CD21-, CD37- }\end{array}$ & TCR+ & $\begin{array}{l}\text { electron beam } \\
\text { PUVA }\end{array}$ & $>355$ \\
\hline NO.12/26 & $60 / \mathrm{M}$ & & plaques/ulceration/tumours/ & $\begin{array}{l}\mathrm{CD} 3+, \mathrm{CD} 4+ \\
\mathrm{UCHL} 1+, \mathrm{CD} 30+, \mathrm{CD} 8\end{array}$ & TCR- & $\begin{array}{l}\text { PUVA } \\
\text { radiotherapy }\end{array}$ & $>12$ \\
\hline NO.13/27 & $39 / \mathrm{M}$ & l & $\begin{array}{l}\text { plaques, } \\
\text { nodules }\end{array}$ & $\begin{array}{l}\text { CD2+, CD3+, } \\
\text { CD5+,CD7+, } \\
\text { CD4+,CD8- }\end{array}$ & TCR+ & None & $>87$ \\
\hline NO.14/11 & 71/M & $\begin{array}{l}\text { left groin } \\
\text { face, thighs, trunk }\end{array}$ & $\begin{array}{l}\text { plaques, papules, } \\
\text { nodules }\end{array}$ & $\mathrm{CD} 3+, \mathrm{CD} 4+; \mathrm{CD} 8-, \mathrm{CD} 22-, \mathrm{CD} 30-$ & TCR+ & $\begin{array}{l}\text { interferon- } \gamma \\
\text { PUVA }\end{array}$ & 48 \\
\hline NO.15/28 & $60 / M$ & / & $\begin{array}{l}\text { erythe-matous } \\
\text { scaly plaques }\end{array}$ & $\begin{array}{l}\text { HLA-DR II+, CD2+,CD3+, CD4+, } \\
\text { CD5+, } \\
\text { CD7+, CD8- }\end{array}$ & / & $\begin{array}{l}\text { PUVA } \\
\text { radiotherapy }\end{array}$ & $>12$ \\
\hline
\end{tabular}


Madridge Journal of Cancer Study \& Research

\begin{tabular}{|c|c|c|c|c|c|c|c|}
\hline NO.16/29 & $34 / \mathrm{M}$ & trunk, scapular & erythematous plaques & / & / & $\begin{array}{l}\text { PUVA } \\
\text { radiotherapy } \\
\text { chlormethine }\end{array}$ & / \\
\hline NO.17/16 & $82 / \mathrm{M}$ & & $\begin{array}{l}\text { erythe-matous } \\
\text { patches }\end{array}$ & $\mathrm{CD} 3+, \mathrm{CD} 45 \mathrm{Ro}+, \mathrm{CD} 43+$ & TCR+ & $\begin{array}{l}\text { interferon- } \gamma \\
\text { PUVA }\end{array}$ & $>27$ \\
\hline NO.18/17 & $52 / \mathrm{M}$ & $\begin{array}{l}\text { face, neck, upper } \\
\text { arms and legs }\end{array}$ & $\begin{array}{l}\text { poikilodermatic healing tumours, } \\
\text { plaques }\end{array}$ & / & TCR+ & $\begin{array}{l}\text { radiotherapy } \\
\text { PUVA Interferon- } \\
\alpha\end{array}$ & 149 \\
\hline NO.19/17 & $88 / \mathrm{M}$ & $\begin{array}{l}\text { trunk } \\
\text { head }\end{array}$ & ulceration/tumour/papules & CD3+ & TCR + & radiotherapy & 32 \\
\hline NO.20/30 & $68 / \mathrm{M}$ & $\begin{array}{l}\text { trunk } \\
\text { right neck } \\
\text { left forearm } \\
\text { groin }\end{array}$ & $\begin{array}{l}\text { erythematous } \\
\text { plaques } \\
\text { tumour } \\
\text { nodes }\end{array}$ & $\begin{array}{l}\text { CD3+,CD45Ro+, CD43+, } \\
\text { CD20- }\end{array}$ & / & systemic chemotherapy & 23 \\
\hline NO.21/20 & $52 / \mathrm{M}$ & trunk, thighs & $\begin{array}{l}\text { plaques } \\
\text { nodules } \\
\text { tumour }\end{array}$ & $\begin{array}{l}\text { CD3+,CD43+, } \\
\text { CD20-,CD79a- }\end{array}$ & TCR+ & $\begin{array}{l}\text { electron beam } \\
\text { radiotherapy } \\
\text { interferon } \\
\text { photopheresis }\end{array}$ & 16 \\
\hline NO.22/15 & $46 / \mathrm{M}$ & upper arm & poikilodermatic & $\begin{array}{l}\text { CD4+,CD74+, } \\
\text { CD45RO+, } \\
\text { BCl-2+, } \\
\text { CD15-,CD20-CD30- }\end{array}$ & / & radiotherapy interferon- $\alpha$ & $>27$ \\
\hline NO.23/31 & $61 / F$ & widespread & $\begin{array}{l}\text { erythematous scaly patches/ } \\
\text { plaques/ulcerated }\end{array}$ & $\begin{array}{l}\text { CD3+,CD4+, CD45RO+, } \\
\text { TIA-1+ }\end{array}$ & TCR+ & gemcitabine & $>12$ \\
\hline NO.24/32 & $69 / \mathrm{M}$ & $\begin{array}{l}\text { forearms, legs, chest, } \\
\text { back }\end{array}$ & ichthyosiform erythematous & CD4+,CD7- & TCR+ & PUVA & $>12$ \\
\hline NO.25/33 & $40 / F$ & chest & $\begin{array}{l}\text { erythematous } \\
\text { tumour } \\
\text { ulceration }\end{array}$ & $\begin{array}{l}\text { CD3+,CD4+, CD5+, } \\
\text { CD45RO+, } \\
\text { CD8+,CD30+ }\end{array}$ & TCR+ & $\begin{array}{l}\text { radiotherapy } \\
\text { oral prednisolone } \\
\text { azathioprine }\end{array}$ & $>60$ \\
\hline NO.26/34 & $55 / \mathrm{M}$ & right thigh & tumor, nodules & / & / & / & / \\
\hline NO.27/35 & $62 / F$ & / & no skin lesions & / & / & steroid & / \\
\hline NO.28/36 & $20 / F$ & $\begin{array}{l}\text { knees ankles } \\
\text { elbows wrists }\end{array}$ & erythema & $\begin{array}{l}\text { CD3+,CD4+ } \\
\text { CD45RO+, } \\
\text { CD8+,CD30-, } \\
\text { CD56-,TIA-1- }\end{array}$ & TCR+ & $\begin{array}{l}\text { interferon, } \\
\text { PUVA, } \\
\text { radiation }\end{array}$ & $>36$ \\
\hline NO.29/37 & $41 / \mathrm{M}$ & chest & $\begin{array}{l}\text { poikiloderma, ichthyosis and } \\
\text { erythematous scaly plaque }\end{array}$ & / & TCR+ & $\begin{array}{l}\text { topical steroids } \\
\text { PUVA }\end{array}$ & 36 \\
\hline NO.30/38 & $75 / F$ & trunk extremities & $\begin{array}{l}\text { brownish maculae } \\
\text { nodupoikilodermatousle-s }\end{array}$ & $\begin{array}{l}\text { BF1+,CD3+,CD8+ } \\
\text { TIA-1+; } \\
\text { CD4-,CD20- } \\
\text { CD56- }\end{array}$ & / & PUVA & $>21$ \\
\hline NO.31/39 & $38 / \mathrm{M}$ & $\begin{array}{l}\text { Chest } \\
\text { upper back }\end{array}$ & erythema poikilodermatous & $\mathrm{LCA}+, \mathrm{CD} 3+$ & / & chemotherapy & / \\
\hline N0.32/40 & $42 / \mathrm{M}$ & $\begin{array}{l}\text { trunk } \\
\text { lower extremities }\end{array}$ & ulceration plaques & / & / & / & / \\
\hline NO.33/41 & $69 / F$ & $\begin{array}{l}\text { Right axillary, } \\
\text { scalp }\end{array}$ & $\begin{array}{l}\text { erythema } \\
\text { papules, } \\
\text { plaque }\end{array}$ & $\begin{array}{l}\beta F 1+, C D 3+, C D 4+ \\
C D 21+, C D 8 \\
C D 20-, C D 30-C D 56-\end{array}$ & TCR+ & / & $>72$ \\
\hline NO.34/42 & $86 / \mathrm{M}$ & head, neck, and hip & tumors & $\begin{array}{l}\text { CD4+,CD68+ } \\
\text { CD7- }\end{array}$ & / & $\begin{array}{l}\text { topical corticosteroid } \\
\text { nb-uvb } \\
\text { irradiation. }\end{array}$ & $>65$ \\
\hline NO.35/43 & $74 / \mathrm{M}$ & / & $\begin{array}{l}\text { macules } \\
\text { plaques }\end{array}$ & / & / & $\begin{array}{l}\text { bexarotene } \\
\text { PUVA }\end{array}$ & / \\
\hline NO.36/44 & $29 / F$ & $\begin{array}{l}\text { extremities, flanks, } \\
\text { buttocks, abdomen, } \\
\text { axillary }\end{array}$ & $\begin{array}{l}\text { depigmented } \\
\text { macules } \\
\text { patches } \\
\text { erythematous } \\
\text { nodules }\end{array}$ & / & / & phototherapy & / \\
\hline NO.37/45 & $88 / F$ & neckline & erythematous plaque telangiectasia & $\begin{array}{l}\text { CD3+,CD4+, } \\
\text { CD5+,CD8+, } \\
\text { CD30- }\end{array}$ & / & topical steroids & $\begin{array}{l}\text { lost to } \\
\text { followup }\end{array}$ \\
\hline Our case & $72 / F$ & $\begin{array}{l}\text { sternum } \\
\text { left upper } \\
\text { extremities }\end{array}$ & scaly plaques, subcutaneous masses & $\begin{array}{l}\text { CD3+,CD4+, } \\
\text { CD5+,CD68+, } \\
\text { CD45RO+,CD8-CD79a-,CD20- } \\
\text { CD30-,CD56-CD1a- }\end{array}$ & TCR+ & prednisone isotretinoin & $>42$ \\
\hline
\end{tabular}

GMF usually presented as non-specific skin lesion such as papule, macule, plaque, desquamation asymptomatic nodule or tumor. Acquired ichthyosis is supposed to be one of the cutaneous manifestations of a variety of malignancies [2]. In recent years, certain GMF cases with an ichthyosi form eruptions have also been reported [3].
Histopathological characteristics of GMF showed the basis of the typical mycosis granuloma (MF) with different quantities of granulomas, with tumor cells and epithelioid cells in filtrating, accompanied by elastic fiber atrophy. Granulomas can be observed in a variety of cutaneous $T$ cell lymphomas (CTCLs), including sezary syndrome, primary 
cutaneous small/medium T cell lymphoma, primary cutaneous anaplastic large cell lymphoma, adult t-cell lymphoma, and primary cutaneous B-cell lymphomas [4-7]. However, GMF is the most common form of primary cutaneous malignant lymphoma showing granulomatous features [8]. About $2 \%$ of CTCLS cases express granuloma formation [9]. Characteristically, multinucleated giant cells showed emperipolesis of lymphocytesor containing phagocytized elastic fibers. Lymphocytic epidermotropism is almost always common. Immunopheno typing of the majority of GMF casesmanifest positive for CD3, CD4, CD5, CD45RO [10], while mostly negative for $C D 8, C D 30$ [11] verses extremely rare CD8-positive in GMF [12]. The analysis of T-cell clonality (TCR-PCR) is helpful for distinguishing granulomatous inflammatory reactions from granulomatous CTCLs, such as GMF.

GMF is easy to be misdiagnosed as inflammatory granuloma or infectious granulomas, such as granuloma annular (GA), sarcoidosis, and so on [13]. Histopathology, immunohistology and TCR gene analysis are helpful in differential diagnosis. A case of GMF presenting as sarcoidosis was reported in 1996 [14]. GMF and granulomatous slack skin (GSS) are both a lymphoma of T-cells, with similar histopathological and immune phenotype. GSS must be differentiated from GMF with the presence of marked epidermotropism, an extensive dermal infiltrate of granulomas, distinct elastophagocytosis and almost completely disappeared elastic fibers $[8,14-15]$. However, it is still difficult to distinguish between the two diseases byhistopathology, while the clinical presentation of GSS is very characteristic, with bulky pendulous axillar and inguinal skin folds [8]. Some scholars hold that GMF is the early stages of GSS and both of them belong to a spectrum of the same entity [16]. Various therapies have been applied to treat GMF including PUVA, glucocorticoid, interferonalpha, retinoids, systemic chemotherapy, radiationand chemotherapy [17-18]. In the current case, we treat the patient with oral prednisoneandisotretinoin. The masses were mainly disappeared after one month of treatment. To consolidate the efficacy, isotretinoin had been continuously administrated for the next 6 months, while prednisone was tapered off after the first month treatment. In May 2013 (2 months after the regimen), a few local skin ulcers appeared on the chest and right lower limb (Fig.5).

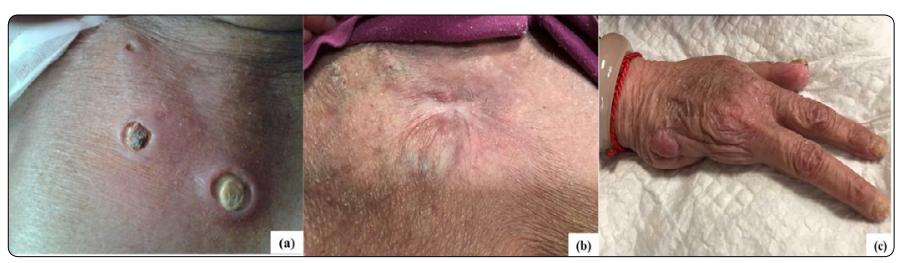

Figure 5. (a) ulcers on the chest; (b) the ulcers were slow to heal; (c) the amputated fingers

After a routine surgical treatment and hormone treatment, the ulcers slowly healed in one month. At present the patient was on prednisone (2.5 mg per day) as maintenance therapy. Patient has been free of tumorous symptoms for more than three years. Prednisone and isotretinoin regimen worked well in this case and avoid spectrum of side effects caused by systemic chemotherapy, radiation and chemotherapy.

The prognosis and clinical significance of granulomatous reaction in MF is not yet clear. Traditionally, granulomatous are an immune mechanism of self-protection, which is helpful for tumor regression and disease remission, and an indicator of favorable prognosis [7, 19]. However, many scholars consider that some patients of CTCL with granulomatous reaction express speedy development, high invasive, poor prognosis, may indicate disease is in progress to those with a poor outcome $[11,20]$. Previous study reported that the 5 -year-survival of GMF was $66 \%$, which was worse than classic MF [9]. Nearly $40 \%$ of GMF patients died for their disease, and $50 \%$ of them died within 5 years of the onset of rashes [12]. In our case, during 52 months follow-up, the skin lesion progressed slowly with no other systemic involvement (Fig.5).

In this case, patient presented with non-specific skin lesion, infiltrative dark erythematous plaques, desquamation, nodule and tumor. Combining clinical manifestations, histopathological examination with TCR gene rearrangement results, the diagnosis of GMF was confirmed. Before the appearance of the rash, there was a mass in her left pinkie without symptoms in September 2008and it then spread to her left ring finger. Histopathological recorded chronic granuloma formation, which might be the early manifestation of GMF. Unfortunately, immunohistochemical and other further examinations were not taken at that time. The presence of granulomatous infiltrate in the early stage of GMF may result in a misdiagnosis. Identification in early stage is critical to prompt treatment and better prognosis, let alone that this patient presented with as rarely described icthyosi form skin eruption in its early stage. It is worth noticing that clinical heterogenicity of GMF is very common. The pathogenesis, the relationship among them, influences on the progression and prognosis are worthwhile studying thoroughly. In the current case, we noted that merely small doses of oral prednisone also achieved good therapeutic effect. Therefore, whether small doses of oral prednisone would be a reliable long-term maintenance treatment therapy for GMF, or only a part of heterogenicity of GMF?

\section{Conflict of interest}

The authors confirm that there is no conflict of interest regarding this manuscript.

\section{References}

1. Ackerman $A B$, Flaxman BA. Granulomatous mycosis fungoides. $\mathrm{Br} J$ Dermatol. 1970; 82: 397-401.

2. Schwartz RA, Williams ML. Acquired ichthyosis: a marker for internal disease. Am Fam Physician. 1984; 29(2): 181-184.

3. Eisman $\mathrm{S}, \mathrm{O}^{\prime}$ Toole EA, Jones $\mathrm{A}$, et al. Granulomatous mycosis fungoides presenting as an acquired ichthyosis. Clin and Exp Dermatol. 2003; 28(2): 174-176.

4. Carrozza PM, Kempf W, Kazakov DV, et al. A case of Sezary's syndrome associated with granulomatous lesions, myelodysplastic syndrome and transformation into CD30-positive large-cell pleomorphic lymphoma. Br J Dermatol. 2002; 147(3): 582-586. 
5. Scarabello A, Leinweber B, Ardigo $M$, et al. Cutaneous lymphomas with prominent granulomatous reaction: a potential pitfall in the histopathologic diagnosis of cutaneous T- and B-cell lymphomas. Am J Surg Pathol. 2002; 26(10): 1259-1268.

6. Li SM. Anaplastic large cel1 lymphoma associated with tuberculoid granulomatous reaction: report of a case. Zhonghua Bing Li Xue Za Zhi. 2006; 35(2): 124-125.

7. Higaki $\mathrm{Y}$, Mizushima J, Kawashima $\mathrm{M}$, et al. Cutaneous granulomas associated with adult T-cell leukemia/lymphoma. Dermatology. 2003; 206(2): 157-160. doi: 10.1159/000068460

8. Kempf W, Ostheeren-Michaelis S, Paulli M, et al. Granulomatous mycosis fungoides and granulomatous slack skin: a multicenter study of the Cutaneous Lymphoma Histopathology Task Force Group of the European Organization for Research and Treatment of Cancer (EORTC). Arch Dermatol. 2008; 144(12):1609-1617. doi: 10.1001/archdermatol.2008.46

9. Shapiro PE, Pinto FJ. The histologic spectrum of mycosis fungoides/ Se'zarysyndrome(cutaneous T-cell lymphoma): a review of 222 biopsies, including newly described patterns and the earliest pathologic changes. Am J Surg Pathol.1994; 18(7): 645-667.

10. Fung MA, Murphy MJ, Hoss DM, et al.Practical evaluation and management of cutaneous lymphoma. J Am.Acad Dermatol. 2002; 46: 325-357.

11. Chen KR, Tanaka M, Miyakawa S. Granulomatous mycosis Fungoides with small intestinal involvement and a fatal outcome. Br J of Dermatol. 1998, 138(3): 522-525.

12. Ishida $M$, Hotta $M$, Takikita-Suzuki $M$, et al. CD8-positive granulomatous mycosis fungoides: a case report with review of the literature. J Cutan Pathol. 2010; 37(10): 1072-1076. doi: 10.1111/j.1600-0560.2010.01577.x

13. Pfaltz K, Kerl K, Palmedo G, et al. Clonality in Sarcoidosis, Granuloma Annulare, and Granulomatous Mycosis Fungoides. Am J Dermatopathol. 2011; 33(7): 659-662. doi: 10.1097/DAD.0b013e318222f906

14. Bessis D, Sotto A, Farcet JP, et al. Granulomatous Mycosis Fungoides Presenting as Sarcoidosis. Dermatology. 1996; 193(4): 330-332.

15. Wollina U, Graefe T, Fuller J. Granulomatous slack skin or granulomatous mycosis fungoides: a case report complete response to percutaneous radiation and interferon alpha. J Cancer Res Clin Oncol. 2002; 128(1): 5054.

16. Metzler G, Schlagenhauff B, Kröber SM, et al. Granulomatous mycosis fungoides: report of a case with some histopathologic features of granulomatous slack skin. Am J Dermatopathol.1999; 21(2): 156-160.

17. Fischer $\mathrm{M}$, Wohlrab J, Audring $\mathrm{TH}$, et al. Granulomatous mycosis fungoides. Report of two cases and review of the literature. J Eur Acad DermatolVenereol.2000;14(3):196-202.doi:10.1046/j.1468-3083.2000.00047.x

18. Zackheim HS. Cutaneous $T$ cell lymphoma: update of treatment. Dermatology. 1999, 199(2): 102-105. doi: 10.1159/000018214

19. Dabski K, Winkelmann RK. Generalized granuloma annulare: clinica1 and laboratory findings in 100 patients. J Am Acad Dermatol. 1989; 20(1): 39-47.

20. Gomez-De La Fuente E, Ortiz PL, Vanaclocha F, et al. Aggressive granulomatous mycosis fungoides with clinical pulmonary and thyroid involvement. $\mathrm{Br} J$ Dermatol. 2000; 142(5): 1026-1029. doi: 10.1046/j.1365-2133.2000.03491.x

21. Schwartz RA, Burgess $G H$, Holtermann $O A$, et al. Mycosis fungoides associated with florid sarcoid reactions. J Surg Oncol. 1980; 14(4): 347-357.

22. Kardashian JL, Zackheim HS, Egbert BM. Lymphomatoid papulosis associated with plaque-stage and granulomatous mycosis fungoides. Arch Dermatol. 1985; 121(9): 1175-1180.

23. Dabski K, Stoll HL. Granulomatous reactions in mycosis fungoides. J Surg Oncol. 1987; 34(4): 217-229. doi: 10.1002/jso.2930340402

24. Argenyi ZB, Goeken JA, Piette WW, Madison KC. Granulomatous mycosis fungoides. Clinicopathologic study of two cases. Am J Dermatopathol. 1992; 14(3): 200-210.
25. Flaxman BA, Koumans JA, Ackerman AB. Granulomatous mycosis fungoides. A 14-year follow-up of a case. Am J Dermatopathol.1983; 5(2): 145-151.

26. Papadavid $E, Y u R C$, Bunker $C$, et al. Tumour progression in a patient with granulomatous mycosis fungoides. Br J Dermatol. 1996; 134(4): 740-743.

27. Sorrells $T$, Pratt $L$, Newton $J$, et al. Spontaneous regression of granulomatous mycosis fungoides in an HIV positive patient. J Am Acad Dermatol.1997; 37(5 Pt 2): 876-880.

28. Telle $H$, Koeppel MC, Jreissati $M$, et al. Granulomatous mycosis fungoides. Eur J Dermatol.1998; 8: 506-510.

29. Maillard $H$, Croué $A$, François $S$, et al. Granulomatous mycosis fungoides histologically simulating cutaneous sarcoidosis. Ann Dermatol Venereol. 1998; 125(12): 912-915.

30. Wong WR, Yang $\amalg$, Kuo TT, et al. Generalized granuloma annulare associated with granulomatous mycosis fungoides. Dermatology. 2000; 200(1): 54-56. doi: 10.1159/000018318

31. Fargnoli MC, Peris K, Francesconi $F$, et al. Granulomatous mycosis fungoides responsive to gemcitabine. 2002; 12: 479-481.

32. Eisman $\mathrm{S}$, O'Toole EA, Jones $\mathrm{A}$, et al. Granulomatous mycosis fungoides presenting as an acquired ichthyosis. Clin Exp Dermatol. 2003; 28(2): 174176.

33. Von Nida J, Randell P, Heenan P. Granulomatous mycosis fungoides with extensive chest wall involvement. 2004; 45:42-46.

34. Shimauchi T, Kabashima K, Tokura Y. CXCR3 and CCR4 double positive tumorcells in granulomatous mycosis fungoides. J Am Acad Dermatol 2006; 54(6): 1109-1111. doi: 10.1016/j.jaad.2006.02.012

35. Sverzellati $N$, Poletti $V$, Chilosi $M$, et al. The crazy-paving pattern in granulomatous mycosis fungoides: high-resolution computed tomography-pathological correlation. J Comput Assist Tomogr. 2006; 30(5): 843-845. doi: 10.1097/01.rct.0000214269.72180.64

36. Hazrati $L N$, Bril $V$, Nag $S$. Muscle and nerve involvement in granulomatousmycosis fungoides. Muscle Nerve. 2007; 36(6): 860-865. doi: $10.1002 /$ mus.20818

37. Morihara K, Katoh N, Takenaka $\mathrm{H}$, et al. Granulomatous mycosis fungoides presenting as poikiloderma. Clin Exp Dermatol. 2009; 34(6): 718-720. doi: 10.1111/j.1365-2230.2008.03013.x

38. Ishida $M$, Hotta $M$, Takikita-Suzuki $M$, et al. CD8-positive granulomatous mycosis fungoides: a case report with review of the literature. J Cutan Pathol. 2010; 37(10): 1072-1076. doi: 10.1111/j.1600-0560.2010.01577.x

39. Gutte R, Kharkar V, Mahajan $S$, et al. Granulomatous mycosis fungoides with hypohidrosis mimicking lepromatous leprosy. Indian J Dermatol Venereol Leprol. 2010; 76(6): 686-690. doi: 10.4103/0378-6323.72470

40. Parker SR, Traywick C, Arbiser JL. Ulcerative granulomatous mycosis fungoides. Skinmed. 2010; 8(3):188-190.

41. Ishida $\mathrm{M}, \mathrm{Okabe} H$. Reactive lymphoid follicles with germinal centers in granulomatous mycosis fungoides: a case report with review of the literature. J Cutan Pathol. 2013; 40(2): 284-285. doi: 10.1111/cup.12012

42. Iwakura T, Ohashi N, Tsuji N, et al. Calcitriol-induced hypercalcemia in a patient with granulomatous mycosis fungoides and end-stage renal disease. World J Nephrol. 2013; 2(2): 44-48. doi: 10.5527/wjn.v2.i2.44

43. Wirtz M, Helbig D. Granulomatous mycosis fungoides: combination therapy with bexarotene and PUVA. Hautarzt. 2014; 65(4): 274-276. doi: 10.1007/s00105-014-2784-5

44. Naeini FF, Soghrati M, Abtahi-Naeini B, et al. Co-existence of various clinical and histopathological features of mycosis fungoides in a young female. Indian J Dermatol. 2015; 60(2): 214. doi: 10.4103/0019-5154.152588

45. Pousa CM, Nery NS, Mann D, et al. Granulomatous mycosis fungoidesadiagnostic challenge. An Bras Dermatol. 2015; 90(4): 554-556. doi: 10.1590/abd18064841.20153460 